\title{
AZ INKLUZÍV INTÉZMÉNYVEZETÉS ÉS AZ INKLUZÍV NEVELÉS-OKTATÁS ÖSSZEFÜGGÉSEI
}

\author{
PERLUSZ ANDREA \\ ELTE Bárczi Gusztáv Gyógypedagógiai Kar \\ Gyógypedagógiai Módszertani és Rehabilitációs Intézet
}

\begin{abstract}
Az inkluzív intézményvezetés fogalma a 2000-es évek elején került be a pedagógiai szakmai gondolkodásba annak a felismerésnek az eredményeképpen, hogy a nevelési-oktatási intézmények vezetőinek meghatározó szerepük van az inklúziós politikák átültetésében, a befogadó gyakorlat és az inkluzív iskolai kultúra eredményes megvalósításában (Ainscow-Sandil 2010; Ruairc 2013). A tanulmányban bemutatott kutatás, melyet a European Agency for Special Needs and Inclusive Education 2019-ben indított (Supporting Inclusive School Leadership, SISL), három szakaszban vizsgálja a részt vevő tagállamok szakpolitikáit, illetve intézményi gyakorlatait. A projekt célja az inkluzív intézményvezetést elősegítő szakpolitikai környezet bemutatása, azoknak a kompetenciáknak a leírása, melyek a sikeres inkluzív intézményvezetőt, illetve intézményvezetést jellemezhetik, illetve a képzés, továbbképzés és a professzionális fejlődés lehetőségeinek támogatása önértékelő eszköz kidolgozásával.
\end{abstract}

Kulcsszavak: inkluzív oktatás, inkluzív intézményvezetés, az inkluzív intézményvezető szerepe és felelössége, szakpolitikai keretrendszer

The concept of inclusive school leadership was introduced into pedagogical professional thinking in the early 2000s, as a result of the realisation that the leaders of educational institutions have a decisive role in transposing inclusive policies, effective implementation of inclusive practices and inclusive school culture (Ainscow and Sandill, 2010; Ruairc, 2013). The research presented in the study, launched by the European Agency for Special Needs and Inclusive Education in 2019 (Supporting Inclusive School Leadership SISL) examines the policies and institutional practices of the participating member states in 3 phases. The aim of the project is to present a policy environment conducive to inclusive institution-management, to describe the competences that can characterise a successful inclusive leader of institution or institution management, and to support the

Levelező szerző: Perlusz Andrea, ELTE Bárczi Gusztáv Gyógypedagógiai Kar Gyógypedagógiai Módszertani és Rehabilitációs Intézet, 1097 Budapest, Ecseri út 3. E-mail: perlusz.andrea@barczi.elte.hu 
opportunities for training, further training and professional development by developing a self-assessment tool.

Keywords: inclusive education, inclusive school leadership, roles and responsibilities of the inclusive school leader, policy framework

\section{Bevezetés}

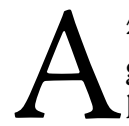

z inkluzív intézményvezetés fogalma a 2000-es évek elején került be a pedagógiai szakmai gondolkodásba annak a felismerésnek az eredményeképpen, hogy a nevelési-oktatási intézmények vezetőinek meghatározó szerepük van az inklúziós politikák átültetésében, a befogadó gyakorlat és az inkluzív iskolai kultúra eredményes megvalósításában (Ainscow-Sandill 2010; Ruairc 2013).

Ha végigtekintünk az integrált nevelés-oktatás, majd az inkluzív oktatatás fejlődéstörténetén, látható, hogy a közel ötven évet átívelő időszakban hogy változtak a fókuszok, s e szerves fejlődés eredményeképpen érkezünk el az intézményvezetők meghatározó szerepének vizsgálatához a témában.

Az óvodai-iskolai integráció Magyarországon a 70-es évek végén kezdődött el, a nyugat-európai integrációs kezdeményezésekkel és mozgalmakkal szinte egy időben. Kezdetben a gyógypedagógiai különnevelés végső céljaként a társadalmi integráció, majd a 80-as évektől mint „az eltérő képességű és fejlettségü gyermekek integrált, közös rendszerben történő nevelésének gondolata” jelenik meg (Lányiné 1987: 933). Kezdetben az egyes fogyatékossági csoportokhoz tartozó gyermekek integrációjának lehetőségei, az adott gyermekek „beilleszthetősége” helyeződött a fókuszba, majd a figyelem az integrációhoz szükséges közoktatási feltételekre helyeződött át. A magyar törvénykezés az 1993-as Közoktatási törvény (LXXIX. törvény a közoktatásról) megalkotásával biztosította minden fogyatékos gyermek számára az oktatáshoz való jogot (a képezhetetlen kategória eltörlése) és kötelezettségként írta elő az integrált oktatás biztosítását is. A speciális intézményrendszer alternatívájaként megteremtődött az integráció lehetősége. Ezzel egy időben rendeletek formájában szabályozta az együttneveléshez szükséges feltételeket (Csányi-Perlusz 2001). Az 1998-ban alkotott Esélyegyenlőségi törvény (1998. évi XXVI. törvény a fogyatékos személyek jogairól és esélyegyenlőségük biztosításáról) alapelvei között kimondta, hogy az állam köteles gondoskodni a fogyatékos személyeket megillető jogok érvényesítéséről, a fogyatékos személyek hátrányait kompenzáló intézményrendszer működtetéséről. E két törvény alapozta meg és tette lehetővé az integrált oktatás és nevelés széles körü megvalósulását (Varga 2006).

Fontos kiemelni, hogy a korábbi, ún. „orvosi modell” (Gereben Ferencné 2004) mellett - mely az egyén fogyatékosságára helyezte a hangsúlyt - fokozatosan került be a pedagógiai és gyógypedagógiai gondolkodásba az ún. „szociális modell” (Könczei-Hernádi 2011), melynek hangsúlya az egyén állapota helyett inkább az egyén és környezete viszonyára, a környezeti feltételek fogyatékosságot csökkentő szerepére hívta fel a figyelmet. Ezzel egyidejüleg különböző kutatások irányultak a befogadó környezet szerepére, az integrált nevelést elősegítő és hátráltató tényezőkre, valamint azokra a 
képzési és továbbképzési lehetőségekre, melyek növelhetik az integráció eredményességét (Köpatakiné 2004; Papp 2001, 2004; Papp et al. 2012; Perlusz-Balázs 2008; Nagyné Schiffer 2011). Az integráció támogatása a hazai közoktatáspolitikában más tanulói csoportok tekintetében is megjelent, mint például a 2003-ban indult, a szociálisan hátrányos és halmozottan hátrányos helyzetü tanulók intézményi környezetét befogadóvá tévő „Integrációs Pedagógiai Rendszer” (IPR) elnevezésű, kompetenciaalapú oktatási program bevezetése (Arató-Varga 2004).

Az inklúzió kifejezést először szociálpolitikai értelemben használták olyan intézkedésekre, amelyek révén felülről kezdeményezetten, direkten avatkoznak be a kirekesztés csökkentése érdekében, kinyilvánítva, hogy a társadalom számára értékesebb a befogadás, mint a diszkrimináció. Ennek következményeként az iskolai befogadás is értékként jelenik meg globálisan a 21. század oktatáspolitikájában, valamint a pedagógiai szakmai mozgalmak koncepcióiban (Nagyné Schiffer 2011). Az inklúzió alatt mindazokat a folyamatos és célzott beavatkozásokat értjük, amelyek az ökoszociális környezet befogadóvá (inkluzívvá) válását azzal érik el, hogy megakadályozzák az adott személyek kirekesztődését és sikeressé teszik részvételüket (Varga 2015). Ezt a folyamatot 1994-ben a spanyolországi Salamancai UNESCO-konferencián alapozták meg, ahol kilencvenkét kormány és huszonöt nemzetközi szervezet foglalkozott az „Oktatás Mindenkinek" (Education for All) címü programmal annak érdekében, hogy kidolgozzák azokat a szükséges és alapvető politikai változtatásokat, melyek elősegíthetik az inkluzív (befogadó) oktatást. A Salamancai nyilatkozat tételei szerint minden gyermeknek joga van a neveléshez a többségi iskolán belül, mely során figyelembe veszik egyéni tulajdonságait, érdeklődési körét, képességeit és tanulási szükségleteit. „Az inklúzióra úgy tekintünk, mint egy olyan folyamatra, amely valamennyi gyerek, fiatal és felnőtt eltérő igényeit figyelembe veszi és reagál rájuk abból a célból, hogy növelje részvételüket a tanulásban, a kultúrához való hozzáférésben és a közösségekben. Ugyanakkor mindezzel csökkenti és kiküszöböli a kizáródásukat az oktatásból (Csányi-Zsoldos 1994; UNESCO 2005, idézi Nagyné Schiffer 2011).

Az UNESCO 2005-ben kiadott inklúziós irányelvei szerint:

1. Az inklúzió egy olyan folyamatként írható le, mely keresi a különbözőségekre adható válaszokat, de közben ezeket a különbözőségeket olyan pozitívumként tekinti, mely a tanulási folyamat ösztönzője lehet.

2. Az inklúzió az akadályok felismerésével, csökkentésével vagy megszüntetésével foglalkozik.

3. Az inklúzió minden gyermek jelenlétéről, részvételéről és eredményességéről szól.

4. Az inklúzió nagy hangsúlyt fektet azokra a tanulókra, akik a kirekesztés vagy az alulteljesítés veszélyének vannak kitéve.

Az inklúzió fogalom a 90-es évektől megjelent a hazai közoktatásban is. Ebben a megjelölésben az a többlet, hogy kifejezi a fogadó intézmény aktivitását. Ez az intézmény nemcsak egyszerűen eltüri, hogy oda egy-egy speciális nevelési szükségletü gyermek jár, hanem tesz is érte: egyénileg differenciált, változatos módszereket, rugalmas tantervi követelményeket alkalmaznak a pedagógusok, szemléletváltozás zajlik a tantestületben, melynek tagjai feladatuknak érzik a körzet valamennyi gyermekének, így a speciális nevelési szükségletü tanulóknak az ellátását is" (Csányi-Zsoldos 1994, idézi Nagyné Schiffer 2011). A méltányosság (equity) elvének elfogadásával olyan intézkedése- 
ket és cselekvéseket kell alkalmazni az egyenlőtlenség ellensúlyozása érdekében, amelyek társadalmi szinten és eszközökkel támogatottan teremtik meg mindenki számára a hozzáférést. Az inkluzivitás akkor teljesül, ha az inklúzióba bevont minden személy esetében érvényesül az egyenlő bánásmód és a méltányosság szempontja is (Varga 2015).

A 2000-es évek elején Booth és Ainscow a fogyatékos gyermekek befogadó nevelésének tapasztalatai alapján kidolgozták az oktatási intézmények befogadóvá tételéhez szükséges feltételeket és lépéseket (Booth-Ainscow 2002, 2011). Bevezették az „Inklúziós Index” fogalmát, mely az intézmény müködésének helyzetelemzésén alapul, $\mathrm{s}$ támogatást nyújt az inkluzív intézményfejlesztési folyamathoz. Az inklúziós index az intézményre vonatkozóan három dimenziót vizsgál: az inkluzív szemlélet kialakítását, a megvalósításhoz szükséges program kidolgozását és a mindennapi gyakorlat megszervezését (Booth-Ainscow 2002).

\section{Az inkluzív intézményvezetés - egy projekt bemutatása}

A European Agency for Special Needs and Inclusive Education az Európai Unió tagországait összefogó szervezet, melynek célja a befogadó oktatásra-nevelésre irányuló együttmüködés elősegítése, az inkluzív intézményekben folyó munka minőségének és hatékonyságának növelése. A szervezet 1996-ban alakult a dán kormány kezdeményezésére, európai szervezetként 1999 óta müködik, melyhez hazánk 2006-ban csatlakozott. Jelenleg 31 tagállam számára biztosítja az ismeretek megosztását szakpolitikai, gyakorlati, illetve kutatási téren egyaránt. A részt vevő tagállamok országonként két föt - egy döntéshozói és egy szakmai képviselöt - delegálnak. Az Agency tematikus projektjei révén olyan témákkal foglalkozik, mint az inkluzív oktatási rendszerek finanszírozása, az inkluzív oktatás támogatásának szervezése, vagy legújabban az inkluzív intézményvezetés segítése, mely jelen tanulmány fókuszában is áll.

A European Agency For Special Needs and Inclusive Education jogelőd intézménye, a European Agency For Development In Special Needs Education már a 2000-es évek elején 15 ország bevonásával vizsgálta, hogy a sikeres inkluzív iskolák milyen módszereket alkalmaznak. Kutatási eredményeik összegzésében elsősorban az empatikus tanári attitűdöt emelték ki. A tanárok részéről szociális érzékenységre, az eltérések elfogadására, a különbségek kezelésének képességére van szükség. Nem kevésbé fontos a pedagógusok szakmai kompetenciája, a támogató iskolai, társadalmi környezet, a határozott kormányzati politika (Halász 2004). A 2019-ben indult, befogadó iskolai vezetést támogató (Supporting Inclusive School Leadership, a továbbiakban SISL) projekt előzményeként zajlott „A tanulók teljesítményének növelése az inkluzív oktatásban” című projekt (Raising the Achievement of All Learners in Inclusive Education 2014-2017), mely az iskolavezetést mint a befogadóbb oktatási rendszer kialakításának kritikus tényezőjét jelölte meg. Összefoglaló jelentésükben kiemelték, hogy az intézményvezetők támogatása az inkluzivitás eredményessé tételében elengedhetetlen.

A SISL projekt - melyben Magyarország is kiválasztásra került Skócia, Svédország és Málta mellett - általános célja annak vizsgálata, hogy hogyan lehet fejleszteni az inkluzív iskola vezetését helyi és nemzeti szintű politikai keretek és támogatási mechanizmusok révén. A SISL projekt során 3 szakaszban vizsgáljuk a részt vevő tagállamok szakpolitikáit, illetve intézményi gyakorlatait, annak érdekében, hogy a projekt végére leírásra kerüljön: 
1. az inkluzív intézményvezetést elősegítő szakpolitikai környezet, vagyis, hogy milyen oktatáspolitikai keretekre van szükség az inkluzív iskolavezetés fejlesztéséhez és támogatásához az oktatási rendszerben;

2. azok a kompetenciák, melyek a sikeres, hatékony inkluzív intézményvezetőt, illetve intézményvezetést jellemezhetik, illetve

3. a képzés, továbbképzés és a professzionális fejlődés lehetőségei, eszközei és jó gyakorlatai, vagyis, hogy milyen támogató szakmai fejlődési lehetőségekre van szükség a hatékony, befogadó iskolavezetők képzéséhez.

A kutatás első fázisának fókuszában a nemzetközi és európai szakpolitikai dokumentumok, irányelvek áttekintése, a szakirodalomban fellelhető adatok rendszerezése és értelmezése állt. Az eddigi munka során 21 országból nyertünk adatokat az intézményvezetést, illetve azon belül is az inkluzív intézményvezetést érintő jogszabályi és szakpolitikai szabályozásról, az iskolavezetők szerepeiről és felelősségi köreiről, a velük szemben megfogalmazott követelményekről (képzettség, végzettség, szakmai tapasztalat és kompetenciák), valamint a szakmai fejlődés és a folyamatos szakmai támogatás lehetőségeiről. A kutatás alapján megállapítható, hogy:

- Nemzetközi szinten kevés az inkluzív intézményvezetést érintő szakirodalmi forrás, hiányoznak a konkrét ajánlások. A nemzeti szinten ezek leginkább a gyógypedagógiai speciális intézmények kontextusában jelennek meg.

- Nem kellően tisztázottak az inkluzív vezetői feladatok.

- Hiányoznak a szakmai fejlődést, a szükséges vezetői kompetenciák megszerzését támogató képzési anyagok, programok. A vezetők képzése többnyire a menedzsment irányítására és az adminisztratív feladatokra összpontosít az inkluzív pedagógiai stratégiák helyett.

- Hiányosságok mutatkoznak abban a tekintetben is, hogy az inkluzív iskolai vezetés számára milyen támogatást biztosítanak a részt vevő országokban.

- Kevés konkrét szabályozót említettek az adatközlők a szakpolitika oldaláról az inkluzív intézményvezetés vonatkozásában.

- Az iskolavezetéssel kapcsolatban három fó elem került azonosításra, amely a sikeres befogadás gyakorlataihoz kapcsolódik: az átalakító vezetés, a megosztott vezetés és az iránymutató vezetés. Ezek középpontjában a közös jövőkép, a közös felelősségvállalás és a döntéshozatal fejlesztése áll. Amikor a vezetés ezen három jellemzője együttesen valósul meg a gyakorlatban, az jelentős pozitív hatást gyakorol a tanulók teljesítményére, a pedagógiai minőségre és az iskola szakmai közösségének fejlődésére.

A projekt 2-3. fázisának célja, hogy meghatározza az inkluzív intézményvezetés fogalmát, standardjait, szakpolitikai ajánlást dolgozzon ki az inkluzív intézményvezetésre vonatkozóan, valamint létrehozzon és kipróbáljon egy önértékelési eszközt, mely hozzájárul az érdeklődő országokban az inkluzív intézményvezetés irányába történő elmozduláshoz.

Jelenleg, a projekt második fázisában alakult ki az inkluzív iskolai vezetés modellje (1. ábra), „A befogadó oktatási rendszerek modellje és jövőképe” (European Agency 2015) eredményeinek felhasználásával: 


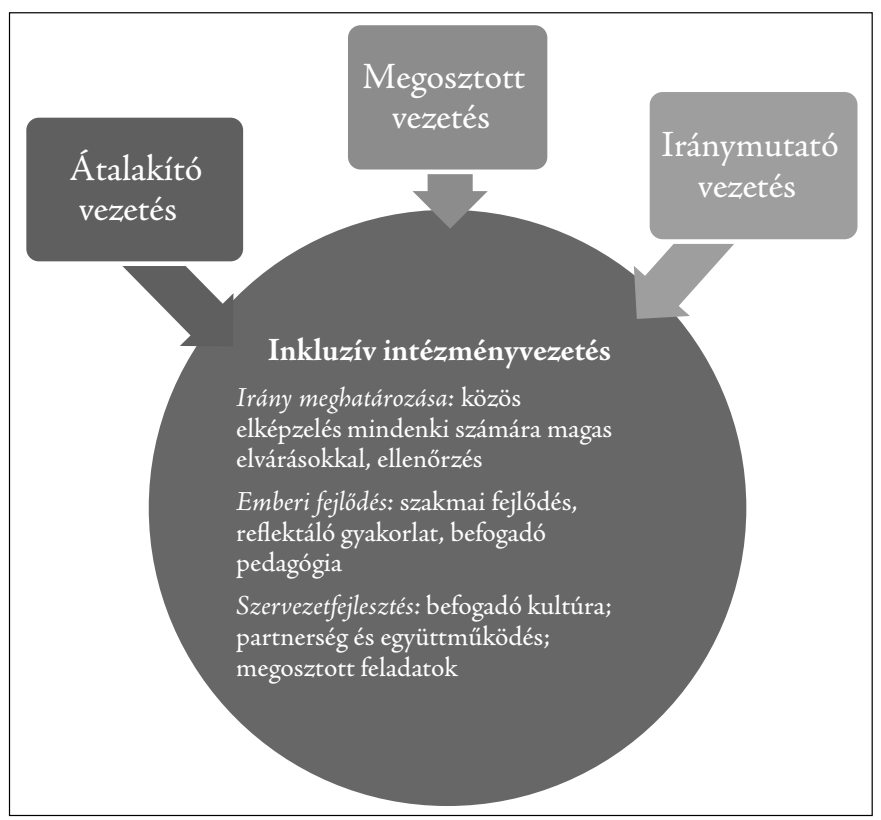

1. ábra: Inkluzív intézményvezetés modellje, SISL projekt

A projekt megközelítése szerint minden vezetés lehet inkluzív, ugyanakkor megkülönböztethetjük az általános intézményvezetés és az inkluzív intézményvezetés jellemzőit. Az inkluzív intézményvezetés modellje szerint az inkluzív iskola vezetőjének (vagy vezetői teamjének) víziója az, hogy minden - nem csupán a sajátos nevelési igényű vagy fogyatékossággal élő - tanuló számára magas színvonalú oktatási lehetőségeket kell biztosítani a helyi közösségben, barátaikkal és társaikkal együtt (European Agency 2015). Az inkluzív intézményvezetők felelősséget vállalnak minden egyes tanulóért, mindegyiküket értékesnek tartják tekintet nélkül képességeikre, szükségleteikre és hátterükre. Azon dolgoznak, hogy biztosítsák minden tanuló teljes részvételét és elkötelezettségét azáltal, hogy meghatároznak egy tisztán kivehető irányt, fejlesztik a nevelőtestületet és a többi érdekelt felet. Minden elérhető eszközt, tapasztalatot és szaktudást felhasználnak annak érdekében, hogy együttmüködésre építve létrehozzanak és fenntartsanak egy befogadó tanulóközösséget, amelynek minden tagját támogatják a lehető legjobb tanulási eredmények elérésében. Az inkluzív intézményvezető partnerséget épít a szülői közösséggel és az iskola külső környezetének szereplőivel. Olyan környezetet teremt, melyben minden tanuló a lehető legjobb tanulási tapasztalatokat szerezheti meg, s a tanulási eredmények elérése mellett a jóllét és a közösséghez tartozás érzését is megtapasztalhatja. Az inkluzív iskolavezetés túlmutat a szervezeten, célja az egyenlőtlenségek kezelése a közösségépítés és a teljes részvétel által. Egy olyan befogadó kultúra fejlesztésére összpontosít, amelyben valamennyi érdekelt fél támogatást kap ahhoz, hogy együtt dolgozzon, értékelje a sokszínűséget, és hogy minden tanuló magas színvonalú oktatást kapjon, beleértve a kirekesztés miatt leginkább veszélyeztetetteket is. Ez a modell épít az oktatás emberi jogi megközelítésére, különös tekintettel a Gyermek jogairól szóló nyilatkozat (United Nations 1989) és a Fogyatékossággal élő személyek jogairól szóló ENSZ-egyezmény (United Nations 2006) legfontosabb elveire. 
A $z$ inkluzív intézményvezetők egyesítik az ún. átalakító, a megosztott és az iránymutató vezetési modell egyes jellemzőit. A transzformációs vagy átalakító vezetés a vezetéstudomány egyik népszerű elmélete Bass (1985) nevéhez kötődik, legfontosabb jellemzője a vezető karizmatikus személyisége és mások motiválásának képessége.

$\mathrm{A} z$ átalakító vezetés az inklúziót meghatározó jövőkép, inspiráció kijelölése szempontjából fontos. Arra összpontosít, hogy az oktatás és a tanulás minőségét javító struktúrákat és kultúrát hozzon létre, meghatározza az irányt és biztosítsa az emberek fejlesztését és a szervezet (újra) definiálását (Day-Sammons 2016). Ezt a vezetői szerepet gyakran hozzák összefüggésbe a változások elindításának képességével és az innovációval, mely az iskolai kultúrára van hatással (Navickaité 2013). A megosztott vezetés koncepciója szerint a vezetés - mint a folyamatok irányítása, befolyásolása, változtatások elindítása - nemcsak az igazgatóra vagy a szükebb iskolavezetői körre (igazgatóhelyettesek, munkaközösség-vezetők) érvényes, hanem minden szereplő hatással van a szervezet kultúrájára, teljesítményére és értékeire, közvetlenül vagy közvetett módon tehát mindenki részt vesz a vezetésben. A megosztott vezetés tehát ennek tudatosítása, illetve tudatos alkalmazása, a feladatok hatékony elosztása, melynek célja, hogy ezzel támogassa mind a szervezethez tartozó személyek, mind a szervezet fejlődését.

Végül az ún. iránymutató vezetés az inkluzív oktatás irányába befolyásolja a humánerőforrást és a szervezeti fejlődést. Hangsúlyozza az egyértelmű oktatási célok kijelölésének, a tanterv megtervezésének, valamint a tanárok és a tanítás értékelésének fontosságát. Az elsődleges hangsúly a vezetők felelősségén van a tanulás-tanítás minőségének javítása területén (Day-Sammons 2016), éppen ezért szokás tanulásközpontú vezetésnek is hívni.

A SISL projekt első fázisának eredményei rámutattak arra, hogy az intézmények vezetőit fel kell ruházni azokkal a tudásokkal, amelyek révén döntéseket tudnak hozni az inkluzív oktatás gyakorlatba ültetése érdekében, ugyanakkor ehhez támogatásra és az inklúzióval kapcsolatos elszámoltathatóságra van szükség.

A projekt szakpolitikai és szakirodalmi háttéranyaga alapján három olyan tényezőt határoztak meg, amelyek támogatják a befogadó iskolák létrehozását, valamint az inkluzív iskolavezetők hatékonyságának növelését.

A három tényező a következő:

\section{Hozzáférés}

- a megfelelő fizetéshez és státuszhoz, a szükséges forrásokhoz, a képzéshez és a szakmai tanulás lehetőségeihez az inkluzív intézményvezetés területén, a nemzeti és helyi oktatáspolitika által támogatottan;

- lehetőség az érdekelt felek széles körével való együttmüködésre a rendszer minden szintjén, ideértve a politikai döntéshozókkal folytatott kommunikációt a hatáskörük kiterjesztése érdekében;

- erőforrásokhoz a munkaerő-kapacitás fejlesztésére és a nemzeti politikai kezdeményezések végrehajtására.

\section{Autonómia}

- az iskola stratégiai irányaival kapcsolatos bizonyítékokon alapuló döntések meghozatalában, a fejlődésben, ideértve például az összes tanuló méltányos oktatására vonatkozó döntéseket; 
- a tanterv rugalmas alkalmazásában, az értékelési és az akkreditációs keretrendszer adaptálásában annak érdekében, hogy teljesüljenek az elvárások, egyúttal megfeleljenek a helyi közösség és a tanulók igényeinek;

- a pedagógusok és egyéb alkalmazottak kinevezésében, akik az innovatív, tanulóközpontú pedagógia révén vállalják a felelősséget és javíthatják az összes tanuló teljesítményét;

- szakértelem biztosításában az iskola fejlesztésének támogatására, a tanulási lehetőségek kibővítésére, valamint az alkalmazottak és a tanulók támogatására;

- a finanszírozás és a források méltányos elosztásában.

\section{Elszámoltathatóság}

- a hozzáférés mértékével és az autonómia szintjével összhangban;

- a jövőkép, az értékek, az eredmények meghatározása, ellenőrzése;

- vezető szerepet töltenek be a folyamatos, rendszeres ellenőrzésben, az önértékelésben és az értékelésben, hogy információkat szolgáltassanak a tanulók eredményeiről.

\section{Inkluzív intézményvezetés - értelmezhetö-e a fogalom hazánkban?}

Magyarországon a köznevelési intézmény és a nevelési-oktatási intézmény vezetőjének feladatait a Nemzeti köznevelési törvény (2011. évi CXC. törvény a nemzeti köznevelésröl) 69. paragrafusa határozza meg. Sem ezek között a tevékenységek között, sem az intézményvezetők pedagógiai-szakmai ellenőrzésének rendszerét meghatározó, 2012-ben megjelent EMMI rendeletben (20/2012. (VIII. 31.) EMMI rendelet a nevelési-oktatási intézmények működéséről és a köznevelési intézmények névhasználatáról) nem kerül külön említésre az inkluzivitás.

Az önértékelés és tanfelügyelet kézikönyveiben (Kézikönyv 2019; Országos Tanfelügyelet 2019), melyek intézménytípusonként elkülönülnek, a vezetői értékelés területeit az Európai Bizottság által támogatott International Co-operation for School Leadership (Nemzetközi együttmüködés az iskolavezetésért 2008-2013) címü projekt keretében kidolgozott iskolavezetői kompetenciák keretrendszere, a Central5 (KözépEurópai Kompetencia Keretrendszer Iskolavezetőknek) alapján definiálják.

E kompetenciák között a tanulás-tanítás területen jelenik meg a befogadás gondolata kulcskompetenciaként: „Az iskolavezetők munkájukban törekszenek egy befogadó tanulási környezet kialakítására." Az inkluzív szemlélet ugyan megjelenik az első terület szempontsorában, de a fogalom tartalma redukálódik a differenciálással és az adaptív oktatással összefüggésben közölt elvárásokra.

Amint Fazekas (2020) megállapítja: „A vezetői tanfelügyelet részeként olyan dokumentumok elemzését is elvégzik a szakértők, mint például a vezetői pályázat, pedagógiai program, éves munkatervek, tanév végi beszámolók. Az elemzésre vonatkozó kérdések között rálelhetünk egy-egy, az inkluzivitás témakörébe tartozó kérdésre, pl.: Hogyan jelenik meg a kiemelt figyelmet igénylö tanulók nevelése, oktatása a vezetési programban? A pedagógiai program alapelvei, céljai, feladatai hogyan támogatják az egyéni bánásmód érvényesülését? Kifejezetten az inkluzív vezetésre vonatkozó kérdés azonban nem szerepel.

A tanfelügyelők helyszíni ellenőrzése során felvett vezetői interjú javasolt kérdéssorában is csupán egy olyan kérdés szerepel, amely a befogadás témájához kapcsolódik 
a vezető feladataival összefüggésben: Mit tesz az inkluzív nevelési-tanulási környezet megteremtése érdekében?" (Fazekas 2020: 24.)

„A 2019/20-as tanévben Fazekas A. az inkluzív intézményvezetés kérdéskörét vizsgálta Celldömölk járás intézményvezetőinek körében, melynek során 22 vezetői interjút készített. Az interjú kérdései érintették az intézménybe járó gyerekek sokszínűségét, az intézmény elhelyezkedéséből fakadó társadalmi háttér jellemzőit, az intézmény partneri kapcsolatait, a dolgozók szemléletét, az inkluzív stratégiákat és gyakorlatot, az inkluzivitást segítő és gátló tényezőket, az intézményvezető szerepét az inkluzív tanulási környezet megteremtésében, illetve az inklúzió eredményességének ellenőrzését, mérését." (Fazekas 2020)

A kutatás során megerősítést nyert, hogy bár hazánkban is vannak magukat inkluzívként definiáló intézmények, azonban az inkluzív intézmény, intézményvezetés nem kidolgozott program szerint történik, ilyen irányú stratégia nem szerepel az intézmények fejlesztési terveiben. A megkérdezett intézményvezetők úgy nyilatkoztak, hogy intézményük inkluzív szemléletü, befogadják a hozzájuk jelentkező gyermekeket, támogatják a sokszínüséget, megvalósítják az esélyegyenlőséget. A szemlélet kialakításában fontos tényező számukra, hogy a nevelőtestület is magáénak érezze az inklúzió gondolatát, fontosságát. Személyes példamutatással próbálnak az intézményvezetők élen járni.

Ahogy az egyik vezető fogalmaz: „A z én célom az, hogy ebben az óvodában a teljes nevelőtestület elfogadja ezt a szemléletet, amit az inkluzív nevelés képvisel. Szeretnék ebben nekik példát mutatni, azt gondolom, én vagyok ebben az élen. El kell tudni fogadni, hogy ha itt ilyen gyerekek élnek, akkor ilyen gyerekeket látunk el. És úgy lássuk el őket, hogy nekik jó legyen.” (Fazekas 2020: 43.)

A kutatás arra is rámutatott, hogy az „intézményvezetők az inkluzív nevelés-oktatást leginkább a sajátos nevelési igényü (SNI), illetve beilleszkedési, tanulási és magatartási nehézséget (BTMN) mutató gyermekek ellátásában értelmezik. „Az óvoda- és iskolavezetők kivétel nélkül kitértek arra, hogy az intézményükben az elmúlt évtizedben nőtt a "papíros« gyerekek, vagyis a sajátos nevelési igényű és a beilleszkedési, tanulási, magatartási nehézségű gyermekek száma. Arányaiban is többen vannak a csökkenő gyereklétszámok miatt kialakult alacsonyabb létszámú csoportokban, osztályokban. Elbeszélésükből érződik, hogy komoly nehézségként élik meg ezeknek a gyermekeknek az egyre nagyobb arányú megjelenését, főleg az iskolákban." (Fazekas 2020: 40.) Többféle stratégiát próbálnak alkalmazni a gyermekek ellátására, egyéni haladásának biztosítására. A vezetők támogatják az attitűdváltást kollégáik körében, ösztönzik az új pedagógiai módszerek bevezetését, továbbképzési lehetőségeket biztosítanak, gyógypedagógus státusz kialakítását szorgalmazzák a fenntartónál, külső szakembereket bíznak meg, együttmüködést szorgalmaznak a pedagógiai szakszolgálattal a BTMN gyerekek ellátásában, pedagógiai asszisztensek alkalmazásával segítik a gyermekek haladását, beilleszkedését, törekednek a gyerekek arányos elosztására a csoportokban, osztályokban, a befogadás elősegítése érdekében pedagógiai programot módosítanak, alapító okirat módosítására tesznek javaslatot." (Fazekas 2020: 40.) A szakmai továbbképzés támogatásában az intézményvezetők szerepüket kulcsfontosságúnak érzik, azonban az ehhez szükséges erőforrások sok esetben nem állnak rendelkezésükre.

$\mathrm{A} z$ inkluzív iskolafejlesztés, inkluzív intézményvezetés tekintetében céljaikat az alábbiakban határozzák meg: 
- az intézmény életét szabályozó dokumentumok (pedagógiai program, helyi tanterv) átalakítása;

- a tanulás támogatása csoportlétszám-csökkentéssel (csoportbontás), egyéni megsegítéssel, új módszerek kipróbálásával;

- a pedagógusok továbbképzésének támogatása;

- inklúziót célzó, korai iskolaelhagyás ellen fellépő program bevezetése (Komplex Alapprogram Koncepciója 2018) (GINOP-6.2.3-17 pályázat ${ }^{1}$ );

- közösségépítő, érzékenyítő programok megvalósítása.

Az inkluzivitást elősegítő tényezők között hangsúlyosan említik az intézmény épületét, a felújítások, korszerüsítések szükségességét, valamint az IKT-eszközöket, a bútorzatot, a fejlesztő eszközöket, továbbá a szülőkkel való együttműködést. Kiemelik az együttműködés jelentőségét egyéb szervezetekkel, mint a Népjóléti Szolgálat, a Védőnői Szolgálat, a Pedagógiai Szakszolgálat, melyek nagymértékben támogatják az inklúzió megvalósulását az intézményeikben.

Gátló tényezőként az intézményvezetők a magas csoport- vagy osztálylétszámokat emelik ki. „Úgy gondolják, hogy egyrészt az inklúzió ellen hat, ha egy jelentkező gyermeket amiatt nem tudnak felvenni, mert már nincs hely, másrészt minél több a gyermek, annál nehezebb az egyéni odafigyelést megvalósítani." (Fazekas 2020: 53.)

További gátló tényezőként jelenik meg a humán erőforrások hiánya, a magas óraadói létszám, föleg a szakos ellátás területén, a nyugdíjas korúak magas száma miatt kialakult vagy kialakulóban lévő pedagógushiány, illetve hogy bizonyos SNI kategóriába tartozó gyermekek ellátásához nincs megfelelő végzettséggel rendelkező szakember a járásban, pl. autizmus spektrumzavar pedagógiája szakos gyógypedagógus. A fenntartóval való együttműködés fontosságát minden interjúalany kiemelte, hiszen az intézmények léte nagyban függ azoktól a forrásoktól, amelyeket a fenntartó számukra biztosítani tud. Ugyanakkor megfogalmazták, hogy a fenntartói támogatás mellett elengedhetetlenek az egyéb anyagi források (pályázat, alapítvány, szponzor, támogató), melyek segítik intézményeiket a mindennapi müködésben, így az inkluzívitás irányába történő fejlesztésben is.

Az interjúalanyok kiemelték továbbá a továbbképzési lehetőségek hiányát vagy a kollégák erre való motiválatlanságát, mely nem független a befogadó szemlélet hiányától, a pedagógusok attitüdjétől. Az intézmény szervezetének irányításában, az inkluzív intézmény megvalósításában a vezetők egyöntetüen számítanak kollégáik együttmüködésére, azonban a pedagógusok megosztottak az inklúzió szemléletének elfogadásában, beállítódásuk, motivációjuk, szakmai megújulás iránti vágyuk eltérő. Az inkluzív intézményi fejlesztés előtt álló akadályként említették továbbá a leterheltséget (tanulókét is), az anyagi megbecsülés hiányát.

„Saját, vagyis intézményvezetői szerepüket az inkluzív nevelési-oktatási környezet megteremtésében jelentősnek gondolják, úgy vélik, az ehhez szükséges feltételek megteremtésében nekik kell élen járni, vezetői koncepciókkal kell rendelkezniük az intézmény egészét illetően, illetve kollégáik elhivatottságát kell növelniük az inkluzivitás érdekében, mert ez az alapja a hatékony müködésnek. Az inklúzió sikerességét, ered-

Gazdaságfejlesztési és Innovációs Operatív Program 6.2.3-17. A SZAKKÉPZÉSI INTÉZMÉNYRENDSZER ÁTFOGÓ FEJLESZTÉSE címü programja. 
ményességét nem mérik az intézmények, mérőeszközök nem állnak rendelkezésre. $\mathrm{Az}$ inkluzív intézményvezetéshez nem találnak központi útmutatást, egyénileg próbálkoznak saját intézményükön belül ezek kialakításával, az inkluzív programok sikerességének, eredményességének mérésére sem rendelkeznek megfelelő eszközökkel. Néhány intézményvezető megemlített saját készítésű, főleg elégedettség mérésére szolgáló kérdőíveket, de alapvetően az intézményekben hiányzik az erre szolgáló mérőeszköz. Egyes vezetők megfogalmazzák ezzel kapcsolatban, hogy ahelyett, hogy tőlük várnák el ezeknek az eszközöknek a kifejlesztését, szívesen fogadnák egy ehhez értő szakember szakmai támogatását." (Fazekas 2020: 65.) Amint Baráth (2006) hivatkozott kutatásából kiemeli: „az intézmény értékelését és önértékelését, a vezetők és a tanárok értékelését kevésbé fontos szempontnak ítélték a válaszadók. Ez feltehetőleg kapcsolatba hozható azzal a ténnyel, hogy a közoktatásban az iskolaértékelésnek nincs kialakult rendszere, az értékelés modern módszerei és eszközei hiányosak, valamint kevés elméleti és gyakorlati felkészültségű szakértő van, aki jártas a szervezetértékelésben, illetve a helyi oktatási rendszer értékelésében. Kulcsprobléma, hogy a fenntartók saját forrásaikból nem tudnak megfelelő forrást biztosítani az értékelésre. Mindezek következtében az intézmények szakmai értékelése esetleges, hiányos. Ebből adódóan rejtve marad az, hogy az értékelés milyen haszonnal járhat az iskola minőségének fejlesztésében. Hasonló problémák fogalmazhatók meg a tanárok és a vezetők értékelésével kapcsolatban is, ennek megoldása csak hosszabb távon, az értékelés helyi és intézményi kompetenciájának folyamatos és fokozatos fejlesztésével tünik megoldhatónak."

$$
* \star *
$$

A jelen tanulmányban bemutatott inkluzív intézményvezetés koncepciója, valamint az ezt középpontba állító SISL projekt eredményei gazdagíthatják az inkluzív nevelésoktatással kapcsolatos tudásunkat. Ahogy a hazai intézményvezetők interjúiból kiderül, annak ellenére, hogy a hazai nevelési-oktatási intézményeknek is nagyfokú tanulói heterogenitással kell megbirkózniuk, az inkluzív oktatás még kevéssé vált értékké, elérendő céllá a hazai gyakorlatban. A nevelési-oktatási intézmények inkluzívvá válásához elsősorban a vezetői és oktatáspolitikai elköteleződésre van szükség, melyhez az inkluzív értékek és gyakorlat megvalósítását célzó és következetesen végigvivő vezetői stratégia nélkülözhetetlen.

\section{IRODALOM}

Ainscow, M. \& Sandill, A. (2010) Developing Inclusive Education Systems: The Role of Organisational Cultures and Leadership. International Journal of Inclusive Education, Vol. 14. No. 4. (June) pp. 401-416.

Arató F. \& Varga A. (2004) Együttmüködés az együttnevelésért. Educatio, Vol. 13. No. 3. pp. 503-507. http://www.hier.iif.hu/hu/educatio_reszletes.php?id=10

BARÁth T. (2006) Az iskolavezetés jellemzői és az intézmény eredményessége, hatékonysága. Új Pedagógiai Szemle, Vol. 56. Nos 7-8. pp. 56-72.

Bass, B. M. (1985) Leadership and Performance beyond Expectations. New York, Free Press.

Bоoтн, T. \& Ainscow, M. (2002, 3rd edition 2011) Index for Inclusion: Developing Learning and Participation in Schools. Revised edition. Bristol (UK), Centre for Studies on Inclusive Education. https://www.eenet.org.uk/resources/docs/Index\%20English.pdf [Letöltve: 2020.03.02.] 
Centrál5: Közép-Európai Kompetencia Keretrendszer Iskolavezetőknek. Tempus Közalapítvány 2013. http://oktataskepzes.tka.hu/content/documents/Central5_fuzet_2013_ HU_web.pdf [Letöltve: 2020. 03.04.]

Csányi Y. \& Perlusz A. (2001) Integrált nevelés - inkluzív iskola. In: Báthory Z. \& FALUS I. (eds) Tanulmányok a neveléstudomány köréböl. Budapest, Osiris Kiadó. pp. 314-332.

CsÁNyi Y. \& Zsoldos M. (1994) Világkonferencia a speciális szükségletűek neveléséről. Új Pedagógiai Szemle, Vol. 44. No. 12. pp. 41-50.

Day, Ch. \& Sammons, P. (2016) The Impact of Leadership on Student Outcomes: How Successful School Leaders Use Transformational and Instructional Strategies to Make a Difference. Educational Administration Quarterly, Vol. 52. No. 2. pp. 221-258.

European Agency (2015) European Agency for Special Needs and Inclusive Education. https:// www.european-agency.org/projects/SISL [Letöltve: 2020. 08. 31.]

European Agency (2020) European Agency for Special Needs and Inclusive Education. https:// www.european-agency.org/sites/default/files/ra_lessons_from_european_policy_and_ practice-web_0.pdf [Letöltve: 2020.08.31.]

Fazeras A. (2020) Az inkluziv intézményröl, inkluziv intézményvezetésröl alkotott vélemények Celldömölk járás intézményvezetöinek körében. Szakdolgozat. Budapest, ELTE BGGYK.

Gereben Ferencné (2004) Diagnosztika és gyógypedagógia. In: Gordosné Szabó A. (ed.) Gyógyitó pedagógia - nevelés és terápia. Budapest, Medicina Könyvkiadó. pp. 87-104.

Halász G. (2004) A sajátos nevelési igényű gyermekek oktatása: európai politikák és hazai kihívások. Új Pedagógiai Szemle, Vol. 54. No. 2. pp. 28-37.

Kézikönyv (2019) Kézikönyv Általános Iskolák számára. Ötödik, javított kiadás 2019. https://www.oktatas.hu/pub_bin/dload/unios_projektek/kiadvanyok/2019_psze/ PSZE_altisk_kezikonyv.pdf [Letöltve: 2020. 03. 07.]

Komplex Alapprogram Koncepciója (2018) A Komplex Alapprogram Koncepciója. Révész László, K. Nagy Emese \& Falus Iván (eds) Eger, Líceum Kiadó.

KönCzei Gy. \& Hernádi I. (2011) A fogyatékosságtudomány főfogalma és annak változásai. In: Nagr ZIta É. (ed.) Az akadályozott és az egészségkárosodott emberek életbelyzete Magyarországon. Kutatási eredmények a TÁMOP 5.4.1 projekt kutatási pillérében. Budapest, Nemzeti Család- és Szociálpolitikai Intézet. pp. 7-28.

Kőpatakiné Mészáros M. (2004) Közben felnő egy elfogadó nemzedék. A sajátos nevelési igényü tanulókat integráltan nevelö-oktató intézmények gyakorlata. Új Pedagógiai Szemle, Vol. 54. No. 2. pp. 38-48.

LÁNyiné Engelmayer Á. (1987) Az integrációs nevelési kísérletek pszichológiai megközelítésből. Pedagógiai Szemle, Vol. 37. No. 9. pp. 931-935.

Nagyné Schiffer Cs. (2011) Az inkluziv iskolák fejlesztése. Doktori (PhD) disszertáció. Budapest, Eötvös Loránd Tudományegyetem Pedagógiai Pszichológiai Kar Neveléstudományi Doktori Iskola.

Navickaité, K. (2013) What Does a City Master Plan Tell about Our Safety? Comparative Analysis of Vilnius, Kaunas, and Klaipeda. Social Sciences, Vol. 80. No. 2. pp. 64-76.

Országos Tanfelügyelet (2019) Országos Tanfelügyelet Kézikönyv Óvodák számára. Ötödik, javított kiadás 2019. https://www.oktatas.hu/pub_bin/dload/unios_projektek/ kiadvanyok/2019_psze/PSZE_ovodai_kezikonyv.pdf [Letöltve: 2020. 03. 07.]

PAPP G. (2002) Tanulásban akadályozott gyermekek iskolai integrációja a szakemberek közötti kooperáció tükrében. Magyar Pedagógia, Vol. 102. No. 2. pp. 159-178.

PApp G. (2004) Tanulásban akadályozott gyermekek a többségi általános iskolában. Pécs, Comenius BT. 
Papp G., Perlusz A., Schiffer Cs., Szenkeres Á. \& Takács I. (2012) Két út van előttem...? Speciális és többségi intézmények közötti kooperáció és konkurencia a sajátos nevelési igényủ tanulók oktatásában. Gyógypedagógiai Szemle, Vol. 40. No. 2. pp. 170-187.

Perlusz A. \& Balázs J. (2008) Az empátia, tolerancia és segítőkészség vizsgálatára kidolgozott eljárás első alkalmazásának tapasztalatai. Iskolakultúra, Vol. 18. Nos 1-2. pp. 92-98.

Ruairc, G. Mac, Ottesen, E. \& Precey, R. (2013) Leadership for Inclusive Education: Values. Vision and Voices Sense Publishers.

VArGA A. (2006) Multikulturalizmus - inkluzív oktatási rendszer. In: Forray R. K. (ed.) Ismeretek a Romológia Alapképzési Szakhoz. Pécs, Pécsi Tudományegyetem Bölcsészettudományi Kar Neveléstudományi Intézet. pp. 145-159.

Varga A. (2015a) Az inklúzió szemlélete és gyakorlata. Pécs, Pécsi Tudományegyetem Bölcsészettudományi Kar, Neveléstudományi Intézet Romológia és Nevelésszociológia Tanszék, Wlislocki Henrik szakkollégium.

VArga A. (2015b) Lemorzsolódás, vagy inklúzió. https://www.academia.edu/11899909/ Lemorzsol\%C3\%B3d\%C3\%A1s_vagy_inkl\%C3\%BAzi\%C3\%B3 [Letöltve: 2020. 03. 06.]

UNESCO (2005) Guidelines for Inclusion: Ensuring Access to Education for All. Document code: ED.2004/WS/39. Collation: 37 p. https://unesdoc.unesco.org/ark:/48223/ pf0000140224

United Nations (1989) Convention on the Rights of the Child United Nations, 1989. https://www.unicef.org/child-rights-convention/what-is-the-convention

United Nations (2006) Convention on the Rights of Persons with Disabilities and Optional Protocol United Nations, 2006. https://www.un.org/disabilities/documents/convention/ convoptprot-e.pdf

1993. évi LXXIX. törvény a közoktatásról. https://mkogy.jogtar.hu/jogszabaly?docid= 99300079.TV [Letöltve: 2020. 08. 28.]

1998. évi XXVI. törvény a fogyatékos személyek jogairól és esélyegyenlőségük biztosításáról. https://net.jogtar.hu/jogszabaly?docid=99800026.tv [Letöltve: 2020. 08. 28.]

2011. évi CXC. törvény a nemzeti köznevelésről. https://net.jogtar.hu/jogszabaly?docid= a1100190.tv [Letöltve: 2020. 08. 28.]

326/2013. (VIII. 30.) Korm. rendelet a pedagógusok előmeneteli rendszeréről és a közalkalmazottak jogállásáról szóló 1992. évi XXXIII. törvény köznevelési intézményekben történő végrehajtásáról. https://net.jogtar.hu/jogszabaly?docid=a1300326.kor [Letöltve: 2020. 02. 28.]

20/2012. (VIII. 31.) EMMI rendelet a nevelési-oktatási intézmények működéséről és a köznevelési intézmények névhasználatáról. https://net.jogtar.hu/jogszabaly? docid=a1200020.emm [Letöltve: 2020. 08. 28.]

1991. évi LXIV. törvény a Gyermek jogairól szóló, New Yorkban, 1989. november 20-án kelt Egyezmény kihirdetéséről. https://net.jogtar.hu/jogszabaly?docid=99100064.tv [Letöltve: 2020. 08. 31.]

2007. évi XCII. törvény a Fogyatékossággal élő személyek jogairól szóló egyezmény és az ahhoz kapcsolódó Fakultatív Jegyzőkönyv kihirdetéséről. https://net.jogtar.hu/ jogszabaly?docid $=\mathrm{a} 0700092 . \mathrm{tv}$

A cikk a Creative Commons Attribution 4.0 International License (https://creativecommons.org/licenses/ by/4.0/) feltételei szerint publikált Open Access közlemény, melynek szellemében a cikk bármilyen médiumban szabadon felhasználható, megosztható és újraközölhető, feltéve, hogy az eredeti szerző és a közlés helye, illetve a CC License linkje és az esetlegesen végrehajtott módosítások feltüntetésre kerülnek. (SID_1) 